\title{
Research on Satisfaction Degree and Factors of Rural Residents on New Rural Cooperative Medical System in Shanxi Province
}

\author{
Wang Xiaofang \\ Tianjin University of Traditional Chinese Medicine \\ TJUTCM \\ Tianjin, China \\ 1468630344@qq.com \\ Chen Xiaoying \\ Tianjin University of Traditional Chinese Medicine \\ TJUTCM \\ Tianjin, China \\ 1194898345@qq.com \\ Liu Cai \\ Tianjin University of Traditional Chinese Medicine \\ TJUTCM \\ Tianjin, China \\ cailiu0707@163.com
}

\author{
He Qiang \\ Tianjin University of Traditional Chinese Medicine \\ TJUTCM \\ Tianjin, China \\ heqiangmail@126.com \\ Zhang Yizhi \\ Tianjin University of Traditional Chinese Medicine \\ TJUTCM \\ Tianjin, China \\ 459640201@qq.com \\ Xue Yun \\ Tianjin University of Traditional Chinese Medicine \\ TJUTCM \\ Tianjin, China \\ 1397042999@qq.com
}

\author{
Zhang Jiahui \\ Tianjin University of Traditional Chinese Medicine \\ TJUTCM \\ Tianjin, China \\ 965271791@qq.com
}

\begin{abstract}
This research is trying to study the present situation of New Rural Cooperative Medical System in Shanxi Province. Through one on one rural resident's answers for questionnaire and random sampling way, the research got the following results. Rural residents are satisfied with this new policy. At the same time, ordered, multiple and classified Logistic regression show that some factors influence the rural residents' attitudes towards the New Rural Cooperative Medical System. First, Health self-evaluation, Second, understanding for the individual payment policy and government subsidies in the New Rural Cooperative Medical System, Third, problems of difficulties in getting medicine treatment, Fourth, inducement of excessive medical treatment and medicine that out of the reimbursement list. Hence, it is necessary to largely propagate the new rural cooperative medicine policy, regulate practices of doctors, and leverage rural residences on this policy and improve satisfaction.
\end{abstract}

Keywords-Rural Residences; New Rural Cooperative Medical System; satisfaction degree

\section{INTRODUCTION}

The New Rural Cooperative Medical System or 'NCMS' for short refers to the policy of medical mutual aid and assistance to farmers. It is organized, guided, supported by the government. Farmers voluntarily participated, individual, collective and government funded, and comprehensive arrangement for serious diseases[1]. Since 2002, the state advocated that all levels of government should actively guide farmers to establish a new type of rural cooperative medical system based on the overall plan for serious diseases. The NCMS has been continuously improved. Subsidies for the NCMS at all levels have been increasing year by year, and the plan for overall compensation has been followed constantly adjusting [2]. To a certain extent, it alleviated the peasants' problem of poverty that due to illness and return to poverty due to illness. In consideration of continuously enhancing of financing level of NCMS, it is critical to formulate appropriate reimbursement and compensation policies. It makes a contribution to improvement of Cognition and Utilization level of rural residents' in NCMS. According to rural residences' 
cognition and utilization of NCMS in Shanxi province, the study explores the factors that can influence rural residences' attitude towards NCMS. In this way, the study put forward some recommendations accordingly.

\section{REFERENCES AND METHODS}

\section{A. Object of Research}

The research object is the part of rural residents in 7 towns under the jurisdiction of Xiaoyi, Shanxi Province.

\section{B. Method of Research}

Method of research is reading literature and designing questionnaire. The questionnaire consists of two parts. First, the social demographic characteristics of the surveyed subjects; Second, the cognition and utilization of the surveyed NCMS reimbursement and compensation proportion. With random sampling way, rural residences in Shanxi province filled in questionnaires one on one. 179 questionnaires were distributed, 179 valid questionnaires were returned, and the efficiency rate was $100 \%$.

\section{Method of Analysis}

To establish a database through EpiData3.0 for data entry and verification. Stata13.0 was used to carry out statistical analysis. So that the study can describe the social demographic characteristics of rural residents and the NCMS reimbursement and compensation policies. To analyze rural residents' satisfaction degree on NCMS ( $<0.05)$. To conduct an ordered multi-classification logistic regression analysis.

\section{RESULTS}

\section{A. Basic information about the object of this research}

1) Social demographic information of the object

Among 179 rural residents surveyed in Shanxi Province, 83 are males, accounting for $46.4 \%$ and 96 females, accounting for $53.6 \%$. There are 9 people who received primary school education or below, accounting for $5 \% .23$ junior high school, accounting for $12.9 \%$. 31 high school, secondary technical school or technical school, accounting for $17.3 \%$, and 116 being junior college or above, accounting for $64.8 \%$. 22(12.3\%) have 2000RMB average annual family income or below. 79(44.1\%) for 2001RMB 10000RMB. 37(20.7\%) for 10001RMB 20000RMB. 15(8.4\%) for 20001RMB 30000RMB. 26(14.5\%) for 30000RMB or above. There are 14 people with family medical expenses below 200RMB, accounting for $7.8 \%$. 65 people with 201RMB to 1000RMB and 65 with 10001RMB to 5000RMB, accounting for $36.3 \%$ respectively. 26 people with 5002RMB-10000RMB, accounting for $14.5 \%$ and $10001 \mathrm{RMB}-20000 \mathrm{RMB}$ respectively. 8 People, accounting for $4.5 \%$. 1 with 20000, accounting for $0.6 \%$. See from TABLE I.

TABLE I. SOCIAL DEMOGRAPHY INFORMATION OF RESEARCH OBJECTS

\begin{tabular}{|c|c|c|c|}
\hline \multicolumn{2}{|r|}{ characteristic } & Numbers of people & percentage \\
\hline \multirow{2}{*}{ Gender } & Male & 83 & $46.4 \%$ \\
\hline & Female & 96 & $53.6 \%$ \\
\hline \multirow{4}{*}{ Education level } & primary school and below degree & 9 & 5 \\
\hline & Junior high school degree & 23 & 12.9 \\
\hline & High school, secondary school or technical school degree & 31 & 17.3 \\
\hline & Junior college degree or above & 116 & 64.8 \\
\hline \multirow{4}{*}{ Age } & 18 and below & 4 & 22 \\
\hline & $18-35$ & 115 & 64.3 \\
\hline & $35-60$ & 54 & 30.2 \\
\hline & 60 and above & 6 & 3.4 \\
\hline \multirow{5}{*}{ Average annual household income } & 2000RMB AND below & 22 & 12.3 \\
\hline & $2001 \sim 10000$ RMB & 79 & 44.1 \\
\hline & 10001 20000 RMB & 37 & 20.7 \\
\hline & 20001 30000 RMB & 15 & 8.4 \\
\hline & 30001 RMB and above & 26 & 14.5 \\
\hline \multirow{6}{*}{ Annual household medical expenditure } & 200RMB and below & 14 & 7.8 \\
\hline & $201 \sim 1000$ RMB & 65 & 36.3 \\
\hline & $1001 \sim 5000 \mathrm{RMB}$ & 65 & 36.3 \\
\hline & $5001 \sim 10000$ RMB & 26 & 14.5 \\
\hline & 10001 20000 RMB & 8 & 4.5 \\
\hline & 20001 RMB and above & 1 & 0.6 \\
\hline
\end{tabular}

\section{2) Physical conditions of the object}

According to objects' survey of their physical condition and prevalence, $33.5 \%$ of them think they are in good condition. $60.3 \%$ think normal. $4.5 \%$ think poor and 3\% think badly. 6(3.4\%) had a serious illness. 27 (15.1\%) had a chronic disease. 34 (19\%) had chronic diseases but not adversely affected normal life. 112 had common illnesses (62.6\%). In addition, according to the survey, 31 of the respondents in the past six months did not get sick. 7 were sick but ignored. 52 took their medication after getting sick. 59 went to the clinic and 7 were in the village hospitals. 15 people went to the county hospital for a check. 8 went to the municipal level, the provincial hospital for hospitalization. See from TABLE II. 
TABLE II. HEALTH CONDITIONS OF THE OBJECT

\begin{tabular}{|c|c|c|c|}
\hline \multicolumn{2}{|r|}{ characteristic } & $\begin{array}{c}\text { Numbers of } \\
\text { people }\end{array}$ & percentage \\
\hline \multirow{4}{*}{ Self-evaluation of one's own physicalcondition } & good & 60 & $33.5 \%$ \\
\hline & normal & 108 & $60.3 \%$ \\
\hline & poor & 8 & $4.5 \%$ \\
\hline & bad & 3 & $1.7 \%$ \\
\hline \multirow{5}{*}{ Your illness condition } & Serious disease & 6 & 3.4 \\
\hline & Chronic and intractable disease & 27 & 15.1 \\
\hline & Chronic disease that with no affection on normal life & 34 & 19 \\
\hline & Common illness & 112 & 62.6 \\
\hline & No disease & 31 & 17.3 \\
\hline \multirow{6}{*}{ Your medical practice within six months } & Had illness but ignored & 7 & 3.9 \\
\hline & took medicine by myself & 52 & 29.1 \\
\hline & Went to clinic & 59 & 33 \\
\hline & Had been hospitalized in village (township, town) clinic (hospital) & 7 & 3.9 \\
\hline & Went to a county hospital to see a doctor & 15 & 8.4 \\
\hline & Had been hospitalized in municipal level, or the provincial hospital & 8 & 4.5 \\
\hline
\end{tabular}

\section{B. Condition of objects' Cognition and Utilization of New Rural Cooperative System}

The results showed that 174 research objects (97.2\%) were willing to continue to participate in the NCMS, and 5 (2.8\%) were unwilling to continue to participate. In addition, when seeking medical treatment at NCMS medical institutions, 40 rural residents (22.4\%) believed that doctors often induce excessive medical expenses or drugs out of the reimbursement list, and $72(40.2 \%)$ think it occasionally. 32 people thought it is few, accounting for $17.9 \%$.

\section{1) Condition of objects' Cognition on NCMS}

There are 46 people who are very clear about the proportion of reimbursement and compensation and the scope of reimbursement, accounting for $25.7 \%$. 76 people who do not know the specific proportion but who have the method to know, accounting for $42.5 \%$. There were 52 people who wanted to know but didn't know from where, accounting for $29.1 \%$. 5 people said they didn't want to know, Accounting for $2.80 \%$. $40.2 \%$ of rural residents who know the amount of personal contributions and subsidies from governments at all levels. $54.2 \%$ of the people said they did not know. Besides, $5.6 \%$ of the rural residents said that they did not care about it. 76 people (42.5\%) were able to learn about NRCMS via electronic media. 95 (53.1\%) learned from paper media and 77 (43\%) were promoted through social security and medical institutions, township and village officials. See from TABLE III.

TABLE III. CONDITION OF OBJECT S’ COGNITION ON NCMS

\begin{tabular}{|c|c|c|c|}
\hline \multicolumn{2}{|l|}{ questions } & $\begin{array}{l}\text { Numbers of } \\
\text { people }\end{array}$ & percentage \\
\hline \multirow{4}{*}{$\begin{array}{l}\text { Do you understand the reimbursement and compensation proportion and } \\
\text { reimbursement scope ( suchas medicine, disease, etc..) }\end{array}$} & Very clear & 46 & $25.7 \%$ \\
\hline & $\begin{array}{l}\text { Don't know the exact proportion, but there's a way to } \\
\text { know. }\end{array}$ & 76 & $42.5 \%$ \\
\hline & Want to know but there is no way & 52 & $29.1 \%$ \\
\hline & Don't want to know, it is useless & 5 & $2.8 \%$ \\
\hline \multirow{3}{*}{$\begin{array}{l}\text { Do you know the amount of annual personal contributions and government } \\
\text { subsidies at all levels }\end{array}$} & Do know & 72 & $40.2 \%$ \\
\hline & Don't know & 97 & $54.2 \%$ \\
\hline & Don't care & 10 & $5.6 \%$ \\
\hline \multirow{3}{*}{ How did you get the information about NRCMS? } & $\begin{array}{c}\text { Electronic channels (Internet, TV, mobile phone, } \\
\text { etc.) }\end{array}$ & 76 & $42.5 \%$ \\
\hline & Paper media ( newspaper, brochure, etc. ) & 95 & $53.1 \%$ \\
\hline & $\begin{array}{l}\text { Publicity from social security and medical personnel, } \\
\text { township and village cadres }\end{array}$ & 77 & $43 \%$ \\
\hline
\end{tabular}

\section{2) Condition of objects' utilization on NCMS}

The proportion of annual medical compensation as a percentage of medical expenses shows that there are 77 people with a ratio of $40 \%$ and below, accounting for $43 \%$. 53 with a ratio of $41 \%-60 \%$, accounting for $29.6 \%$. 20 with a ratio of $61 \%-80 \%$, accounting for $11.2 \%$. The impact of NRCMS on medical expenditure was $19 \%$ (34), 35.8\% (64), 21.8\% (39), $1.7 \%$ (3 people), $21.8 \%$ (39 people) respectively. With the decrease of outpatient service expenditures, the decrease of hospital expenses, the increase of medical expenses, and no change, etc. 31 people think that joining the NRCMS has greatly improved the situation of "seeing a doctor hard and seeing a doctor expensive". 115 people think there is some improvement. 26 people think that there is no improvement at all, and 7 people did not consider this issue. See from TABLE IV. 
TABLE IV. CONDITION OF OBJECTS' UTILIZATION ON NCMS

\begin{tabular}{|c|c|c|c|}
\hline \multicolumn{2}{|c|}{ Content } & \multirow{2}{*}{$\begin{array}{c}\text { Numbers of people } \\
106\end{array}$} & \multirow{2}{*}{$\begin{array}{c}\text { Percentage } \\
59.2 \% \\
\end{array}$} \\
\hline \multirow{4}{*}{$\begin{array}{l}\text { Your annual medical compensation } \\
\text { proportion in medical expenses }\end{array}$} & $40 \%$ or below & & \\
\hline & $41 \%-60 \%$ & 53 & $29.6 \%$ \\
\hline & $61 \%-80 \%$ & 20 & $11.2 \%$ \\
\hline & $80 \%$ OR ABOVE & 0 & $0 \%$ \\
\hline \multirow{5}{*}{$\begin{array}{c}\text { The impact of NCMS on your Medical } \\
\text { Expenditure }\end{array}$} & Outpatient expenditure decreased & 34 & $19 \%$ \\
\hline & Hospitalization expenses decreased & 64 & $35.8 \%$ \\
\hline & Both decreased & 39 & $21.8 \%$ \\
\hline & No change & 39 & $21.8 \%$ \\
\hline & Medical expenditure increased & 3 & $1.7 \%$ \\
\hline \multirow{4}{*}{$\begin{array}{l}\text { Do you think participation in NCMS has } \\
\text { improved the situation of "difficult and } \\
\text { expensive to see a doctor"? }\end{array}$} & There's been a lot of improvement. & 31 & $17.3 \%$ \\
\hline & A certain degree of improvement & 115 & $64.3 \%$ \\
\hline & No improvement at all. & 26 & $14.5 \%$ \\
\hline & Never thought about it. & 7 & $3.9 \%$ \\
\hline
\end{tabular}

\section{3) Advantages of NCMS}

The results showed that among the advantages of NCMS, only $33.5 \%$ of people think it could be reimbursed. $65.4 \%$ think it could help see a doctor in time, and $45.3 \%$ think it could be a security if they had a serious illness. $70.0 \%$ of the rural residents think that their advantage is that they can see a doctor at a nearby hospital. 83.2\% think NCMS can prevent doctors from charging arbitrarily; $73.7 \%$ of people think the government, collectives will have some subsidies. See from TABLE V.

TABLE V. ADVANTAGES OF NCMS

\begin{tabular}{|c|c|c|c|c|}
\hline \multirow{2}{*}{ Content } & \multicolumn{2}{|c|}{ yes } & no & Percentage(\%) \\
\cline { 2 - 5 } & Numbers of people & Percentage(\%) & 119 & 66.5 \\
\hline $\begin{array}{c}\text { Be able to reimburse part of the } \\
\text { medical expenses }\end{array}$ & 60 & 33.5 & 62 & 34.6 \\
\hline Can see a doctor in time & 117 & 65.4 & 98 & 54.7 \\
\hline $\begin{array}{c}\text { Have security on some serious } \\
\text { diseases }\end{array}$ & 81 & 45.3 & 52 & 30 \\
\hline Can see a doctor at nearby & 127 & 70.0 & 40 & 16.8 \\
\hline $\begin{array}{c}\text { Prevent from unreasonable charge } \\
\text { The government, the collective } \\
\text { will subsidies some }\end{array}$ & 149 & 83.2 & 47 & 26.3 \\
\hline
\end{tabular}

\section{Single Factor Analysis on Satisfaction of Rural Residents} with NCMS

Numbers of rural residents, satisfied, ordinary, unsatisfied with NCMS, are 26 (14.5\%), 149(83.3\%), 4 (2.2\%) respectively. Chi - square test was conducted on the satisfaction of the rural residents in different characteristics in
Shanxi Province: age, annual household per capita income, annual household medical expenditure, self - assessment health, whether know well about personal contribution and government subsidy amount, improvements of difficulty and high cost to access medical service, over-treatment and prescription of drugs out of the reimbursement list. There was statistical difference. $(\mathrm{P}<0.05)$. See from TABLE VI

TABLE VI. A COMPARATIVE STUDIES ON THE SATISFACTION DEGREE OF NEW RURAL COOPERATION POLICY AMONG RURAL RESIDENTS WITH DIFFERENT CHARACTERIST ICS

\begin{tabular}{|c|c|c|c|c|c|c|c|c|c|}
\hline \multirow{2}{*}{\multicolumn{2}{|c|}{ Variables }} & \multicolumn{2}{|c|}{ Unsatisfied } & \multicolumn{2}{|c|}{ normal } & \multicolumn{2}{|c|}{ Satisfied } & \multirow{2}{*}{$\chi^{2}$} & \multirow{2}{*}{$\mathbf{P}$} \\
\hline & & Numbers & Percentage(\%) & Numbers & Percentage(\%) & Numbers & Percentage(\%) & & \\
\hline \multirow{2}{*}{ Gender } & Male & 0 & 0.0 & 74 & 89.2 & 9 & 10.8 & \multirow[t]{2}{*}{5.553} & \multirow[t]{2}{*}{0.062} \\
\hline & Female & 4 & 4.2 & 75 & 78.1 & 17 & 17.7 & & \\
\hline \multirow{4}{*}{ Education level } & $\begin{array}{c}\text { Primary school or } \\
\text { below }\end{array}$ & 0 & 0.0 & 9 & 100 & 0 & 0.0 & \multirow{4}{*}{6.855} & \multirow{4}{*}{0.334} \\
\hline & Junior high school & 0 & 0.0 & 17 & 73.9 & 6 & 26.1 & & \\
\hline & $\begin{array}{c}\text { High } \\
\text { school/secondary } \\
\text { school/technical } \\
\text { school }\end{array}$ & 0 & 0.0 & 28 & 90.3 & 3 & 9.7 & & \\
\hline & $\begin{array}{c}\text { Junior college or } \\
\text { above }\end{array}$ & 4 & 3.5 & 95 & 81.9 & 17 & 14.7 & & \\
\hline \multirow{4}{*}{ Age } & $\begin{array}{c}18 \text { years old and } \\
\text { below }\end{array}$ & 2 & 50.0 & 0 & 0.0 & 2 & 50.0 & \multirow{4}{*}{51.918} & \multirow{4}{*}{0.000} \\
\hline & 18 35 years old & 2 & 1.7 & 94 & 81.7 & 19 & 16.5 & & \\
\hline & $35 \sim 60$ years old & 0 & 0.0 & 49 & 90.7 & 5 & 9.3 & & \\
\hline & $\begin{array}{c}61 \text { years old and } \\
\text { above }\end{array}$ & 0 & 0.0 & 6 & 100 & 0 & 0.0 & & \\
\hline
\end{tabular}




\begin{tabular}{|c|c|c|c|c|c|c|c|c|c|}
\hline \multicolumn{10}{|c|}{ Cont. To TABLE VI } \\
\hline \multirow{4}{*}{$\begin{array}{l}\text { Annual household per- } \\
\text { capita income }\end{array}$} & 2000RMB or below & 0 & 0.0 & 17 & 77.3 & 5 & 22.7 & \multirow{4}{*}{13.956} & \multirow{4}{*}{0.030} \\
\hline & 2001 10000 RMB & 4 & 5.1 & 62 & 78.5 & 13 & 16.5 & & \\
\hline & $10001 \sim 20000$ RMB & 0 & 0.0 & 37 & 100 & 0 & 0.0 & & \\
\hline & $\begin{array}{l}\text { 20001RMB and } \\
\text { above }\end{array}$ & 0 & 0.0 & 33 & 80.5 & 8 & 19.5 & & \\
\hline \multirow{4}{*}{$\begin{array}{l}\text { Annual household } \\
\text { medical expenditure }\end{array}$} & 200RMB and below & 0 & 0.0 & 9 & 64.3 & 5 & 35.7 & \multirow{4}{*}{15.275} & \multirow{4}{*}{0.018} \\
\hline & 201 1000RMB & 4 & 6.2 & 50 & 76.9 & 11 & 16.9 & & \\
\hline & 1001 5000RMB & 0 & 0.0 & 60 & 92.3 & 5 & 7.7 & & \\
\hline & 5001RMB and above & 0 & 0.0 & 30 & 85.7 & 5 & 14.3 & & \\
\hline \multirow{4}{*}{ Self-rated health } & bad & 0 & 0.0 & 3 & 100 & 0 & 0.0 & \multirow{4}{*}{13.644} & \multirow{4}{*}{0.03} \\
\hline & poor & 0 & 0.0 & 8 & 100 & 0 & 0.0 & & \\
\hline & good & 4 & 3.7 & 94 & 87.0 & 10 & 9.3 & & \\
\hline & Very good & 0 & 0.0 & 44 & 73.3 & 16 & 26.7 & & \\
\hline \multirow{4}{*}{ Prevalence } & Serious disease & 0 & 0.0 & 6 & 100 & 0 & 0.0 & \multirow{4}{*}{4.057} & \multirow{4}{*}{0.669} \\
\hline & $\begin{array}{c}\text { Chronic and } \\
\text { intractable disease }\end{array}$ & 0 & 0.0 & 23 & 85.2 & 4 & 14.8 & & \\
\hline & $\begin{array}{c}\text { Chronic non- } \\
\text { obstinate disease }\end{array}$ & 0 & 0.0 & 30 & 88.2 & 4 & 11.8 & & \\
\hline & Common disease & 4 & 3.6 & 90 & 80.4 & 18 & 16.1 & & \\
\hline \multirow{3}{*}{$\begin{array}{l}\text { Reimbursement and } \\
\text { compensation policy }\end{array}$} & Don't want to know & 0 & 0.0 & 5 & 100 & 0 & 0.0 & \multirow{3}{*}{6.313} & \multirow{3}{*}{0.177} \\
\hline & Don't know & 4 & 3.1 & 109 & 85.1 & 128 & 11.7 & & \\
\hline & Do know & 0 & 0.0 & 35 & 76.1 & 46 & 23.9 & & \\
\hline \multirow{2}{*}{$\begin{array}{l}\text { Do you understand } \\
\text { personal contribution and } \\
\text { government subsidy } \\
\text { amount }\end{array}$} & Do know & 0 & 0.0 & 57 & 79.2 & 15 & 20.8 & \multirow[b]{2}{*}{6.232} & \multirow[b]{2}{*}{0.044} \\
\hline & Don't know & 4 & 3.7 & 92 & 86.0 & 11 & 10.3 & & \\
\hline \multirow{4}{*}{$\begin{array}{l}\text { Proportion of medical } \\
\text { compensation to medical } \\
\text { expenditure }\end{array}$} & $40 \%$ and below & 4 & 3.8 & 88 & 83.0 & 14 & 13.2 & \multirow{4}{*}{3,990} & \multirow{4}{*}{0.407} \\
\hline & $41 \% \sim 60 \%$ & 0 & 0.0 & 43 & 81.1 & 10 & 18.9 & & \\
\hline & 61\% $80 \%$ & 0 & 0.0 & 18 & 90.0 & 2 & 10.0 & & \\
\hline & $81 \%$ and above & 0 & 0.0 & 0 & 0.0 & 0 & 0.0 & & \\
\hline \multirow{2}{*}{$\begin{array}{c}\text { Whether the situation of } \\
\text { difficulty and high cost to } \\
\text { get medical services } \\
\text { improved }\end{array}$} & yew & 0 & 0.0 & 121 & 82.9 & 25 & 17.1 & \multirow[b]{2}{*}{21.390} & \multirow[b]{2}{*}{0.000} \\
\hline & know & 4 & 12.1 & 28 & 84.9 & 1 & 3.0 & & \\
\hline \multirow{2}{*}{$\begin{array}{l}\text { Whether over treatment or } \\
\text { prescription of drugs out } \\
\text { of reimbursement exists }\end{array}$} & yes & 4 & 2.8 & 124 & 86.1 & 16 & 11.1 & \multirow[b]{2}{*}{7.611} & \multirow[b]{2}{*}{0.022} \\
\hline & no & 0 & 0.0 & 25 & 71.4 & 10 & 28.6 & & \\
\hline
\end{tabular}

\section{Multi - factor Analysis on Satisfaction of Rural Residents with NCMS}

The satisfaction degree of rural residents in Shanxi Province for the NCMS was taken as the dependent variable and the independent variable was taken as a variable with statistical significance. To do an ordered multi-classification Logistic regression analysis. The results showed that self- assessment of health, understanding of the new rural cooperative individual payment policy and government subsidies, the improvement on the situation of difficulty and high cost to get medical services. The existence of induced excessive medical treatment or out-of-catalog drug reimbursement is the influencing factors of rural residents' satisfaction with NCMS policy in Shanxi Province. See from TABLE VII.

TABLE VII. MULTIVARIATE LOGISTIC REGRESSION ANALYSES OF NCMS

\begin{tabular}{|c|c|c|c|c|c|c|c|}
\hline Variable name & \multicolumn{2}{|c|}{$\begin{array}{l}\text { Control } \\
\text { group }\end{array}$} & Coefficient & $\begin{array}{c}\text { Standard } \\
\text { error }\end{array}$ & $\begin{array}{c}\mathrm{P} \\
\text { value }\end{array}$ & $\begin{array}{c}\text { OR } \\
\text { value }\end{array}$ & $\begin{array}{c}\text { OR } \\
\text { value95\%CI } \\
\end{array}$ \\
\hline Age & & & -0.090 & 0.469 & 0.847 & 0.914 & $0.364 \sim 2.291$ \\
\hline Average annual per capital income & & & 0.001 & 0.203 & 0.998 & 1.001 & $0.673 \sim 1.488$ \\
\hline Annual household medical expenditure & & & 0.131 & 0.256 & 0.609 & 1.140 & $0.690 \sim 1.884$ \\
\hline Self-rated physical condition & & & 1.515 & 0.453 & 0.001 & 4.550 & $1.873 \sim 11.051$ \\
\hline $\begin{array}{l}\text { Do you know individual payment Policy and Government subsidy of } \\
\text { NCMS? }\end{array}$ & YES & NO & 1.432 & 0.537 & 0.008 & 4.188 & $1.461 \sim 12.009$ \\
\hline Whether difficulty for getting medical services get improved? & YES & $\mathrm{NO}$ & 3.356 & 1.137 & 0.003 & 28.672 & $3.088 \sim 266.255$ \\
\hline $\begin{array}{l}\text { Whether over-treatment or prescription of drugs out of reimbursement } \\
\text { list exists? }\end{array}$ & NO & YES & 1.658 & 0.566 & 0.003 & 5.247 & 1.729 15.929 \\
\hline
\end{tabular}

Age, annual per capita income, self-rated health are listed from low to high. The higher the score, the higher the age. The higher the annual per capita income, the better the self-rated health.

\section{DisCussions and ReCOMmendations}

Rural residents in Shanxi Province are more satisfied with the NCMS, which shows that the situation of "difficulty and high-cost to get medical services". After joining the NCMS, the situation has been improved. Only $14.5 \%$ of the rural residents 
are dissatisfied. It can be seen that the new rural cooperative medical system plays a certain role in the process of medical treatment for rural residents after the new medical reform, which is quite consistent with the farmers' satisfaction rate of the new rural cooperative medical policy studied by Qi Yumei and others [3]. 97. $2 \%$ of the rural residents were willing to continue to participate in the policy, which proved that NCMS had made some achievements. However, there are some problems in the operation of NCMS. For example, the awareness of rural residents about NCMS is too low. In addition, more than half of the residents say that their annual medical compensation accounts for less than $40 \%$ of the medical expenditure. It can be seen that the proportion of NCMS compensation and the insurance level is relatively low. This is in agreement with Wang Ning [4] and Zhang Yibing [5] 's conclusion in the farmer's investigation of the NCMS. They believe that the farmer's awareness of the NCMS reimbursement policy and procedure is low and the NRCMS compensation rate is low and the level of protection is low. What's more, the study shows that when rural residents are getting medical treatment, doctors are tending to induce over treatment and prescribe drugs that out of the reimbursement list. Therefore, the relevant institutions of the new rural cooperative medical system should actively carry out health education and publicity work of NCMS. For example, to carry out health talks in village clinics. Make some NCMS leaflets, etc.. To simplify the NCMS reimbursement process and reasonably expand the scope of reimbursement[5]. Through perfecting the reimbursement policy of NCMS and strengthening propaganda, to enhance residents' awareness of health risk, improve the cognitive utilization of NCMS and the satisfaction of rural residents of NCMS.

In univariate analysis, the younger rural residents are more satisfied with NCMS, which may be due to the good physical condition and knowledge of young people, the understanding of NCMS policies and the low utilization rate of NCMS. The higher the per capita income and the lower the annual family medical expenditure, the better the satisfaction of rural residents to NCMS. This is due to the fact that rural residents with high income or low family medical expenses do not rely on the NCMS reimbursement and compensation mechanism in the process of medical treatment. So they have a high degree of satisfaction with NCMS. It is consistent with Qi Yumei.'s [3) conclusion of that there is a statistical difference in the cognition and the scope of service of NCMS due to the difference of age and annual household income. In multivariate regression analysis, the better self-rated health was, the better the satisfaction degree of NCMS was 4.550, $\mathrm{P}<0.05$. This may be due to the better self-rated health status and the less chance of illness among rural residents. The low degree utilization of the new agricultural cooperation. Therefore, they are more satisfied. The satisfaction rate of rural residents who knew the amount of individual contributions and government subsidies was 4.188 times higher than that of understood rural residents. This may be due to the better utilization of NCMS by rural residents who understand the NCMS policies. It is consistent with Yue Ai'. [6] In the study of the relationship between the cognitive level of NCMS and the medical expenditure and the actual compensation ratio of farmers. The result shows that cognition influence farmers' satisfaction with
NCMS. The residents who thought that "difficulty and high cost to get medical services" improved were more satisfied than those who had no change $(\mathrm{P}<0.05)$. May be rural residents with high utilization rate of NCMS have improved their "difficult and expensive medical treatment", so the satisfaction degree of NCMS is high. In addition, the satisfaction degree of NCMS in rural residents who considered the existence of over treatment or prescription of drugs without reimbursement was lower than that of non-encountered rural residents $(5.247, \mathrm{P}<0.05)$. This is due to the fact that excessive inducement of medical personnel to seek medical treatment or to prescribe non-reimbursable drugs. It can lead to resistance among residents. As a result, satisfaction degree with NCMS was reduced. To sum up, village clinics and community health and medical institutions should expand the medical service scope, conduct regular physical examination, health education and vaccination, [7] and improve the residents' physical condition. The relevant departments should further improve the new rural cooperative policy, increase the proportion of new rural cooperative reimbursement and increase the utilization rate of rural residents. This can enhance the attraction of NCMS to rural residents, more than simply providing protection for serious illness. Besides, to standardize practitioners' practices and establish strict rules and regulations for preventing physicians from inducing past medical behaviors. Under certain conditions, patients should be treated as much as possible in the medical insurance catalog. To reduce the cost of medical treatment and improve the satisfaction of NCMS among rural residents.

\section{REFERENCES}

[1] General Office of the State Council. Opinions on the Establishment of a New Rural Cooperative Medical system[S].2003-01-16.

[2] Health Min istry and Finance. Min istry. Notice on doing well the work of New Rural Cooperative Medical systemon 2008[S].2008-03-13.

[3] Qi Yumei, Wang Shengfeng, Wang Guihua. Investigation on Farmers' Cognition of New Rural Cooperative Medical system in Hubei Province[J]. Chinese General Practice. 011, 14(3B)pp. 879-880.

[4] Wang Ning. Investigation on Farmers' Cognition of New Rural Cooperative Medical system in Fenyang City in 2011. Journal of Baotou Medical College. 2012,28(4)pp.21,28.

[5] Zhang Yibing, Yuan Xinyu, li shuo. Research on the Effect of New Rural Cooperative Medical Insurance System - W ith Kaihua County in Zhejiang Province as an Example [J].Chinese market. 2016, 870 (3)pp.43-45.

[6] Yue Ai, Yi Hongmei, Shi Yaojiang, etc. A Study on the Relationship between NRCMS Level and Peasants'Medical Expenditure and Actual Compensation Ratio - A Follow-up Survey Based on 2020 Peasant Households in Five Provinces [J]. Health economic research.2015, 333(1)pp.60-63.

[7] Chen Airu. The New Rural Cooperation Service Cornerstone: research on Rural Medical Service system [J]. Primary health care in China. 2008,22(10)pp.1-3. 